\title{
26. A short critique on Dylan Thomas's “Do Not Go Gentle Into That Good Night”
}

\section{Mahmut KAYAALTI}

APA: Kayaaltı, M. (2021) A short critique on Dylan Thomas's "Do Not Go Gentle Into That Good Night". RumeliDE Dil ve Edebiyat Araştırmaları Dergisi, (Ö9), 329-335. DOI: 10.29000/rumelide.984784.

\begin{abstract}
As a prominent representative of the Neo-romantic movement in the 1940s, Dylan Thomas, with his poem "Do Not Go Gentle Into That Good Night" (1952), presents his thoughts on the phenomenon of death. Contrary to the main idea in other death-themed poems, this poem depicts that though death's inevitability is known, one should not accept death all at once. Instead, people should fight to get as much time from death as possible. Even though Thomas's advice encourages resistance to death, it contains some uncertainty about how this resistance should be. How and why does a human try to take time off death, knowing that the impending doom will come sooner or later? Moreover, Thomas has been said to produce this poem for the sake of his ill father, and this makes difficult to recognize the audience he intended. Has the poem been written to uplift his dying father? Or is it for Thomas' readers to know the poet's thoughts on death? Accordingly, this paper has been prepared to examine the implications in the tercets in-depth to investigate Thomas's approach to the concept of death, and to shed light on Thomas's target group with his poem. The study reveals that the failures and regrets, which are highlighted by Thomas to refuse the death, are insufficient to motivate people to stay more on earth.
\end{abstract}

Keywords: Dylan Thomas, death, neo-romantic, forties' poetry, gentle

\section{Dylan Thomas'ın “Do Not Go Gentle Into That Good Night” șiiri üzerine kısa bir eleștiri}

$\ddot{0} \mathbf{z}$

1940'lardaki Neo-romantik akımın önemli bir temsilcisi olan Dylan Thomas, "Do Not Go Gentle Into That Good Night" (1952) şiiriyle ölüm olgusuna ilişkin düşüncelerini sunmaktadır. Diğer ölüm temalı şiirlerdeki ana fikrin aksine; bu şiir, ölümün kaçınılmazlı̆̆ının bilindiğini, dolayısıyla ölümün bir anda kabul edilmemesi gerektiğini anlatır. Bunun yerine, insanlar ölümden mümkün olduğunca fazla zaman almak için ölüme karşı mücadele göstermelidir. Thomas'ın tavsiyesi ölüme karşı direnişi teşvik etse de, şiir bu direnişin nasıl olması gerektiği konusunda bazı belirsizlikler içermektedir. Bir insan, yaklaşan kıyametin er ya da geç geleceğini bilerek, ölümden nasıl ve neden zaman ayırmaya çalışır? Ayrıca Thomas'ın bu şiiri hasta babası için yazdığı söylenmektedir, bu da hedeflediği kitlenin tanınmasını zorlaştırmaktadır. Şiir, ölmek üzere olan babasına moral vermek için mi yazıldı? Yoksa, Thomas'ın okurlarının, şairin ölüm hakkındaki düşüncelerini bilmeleri için mi? Sonuç olarak bu makale, Thomas'ın ölüm kavramına yaklaşımını irdelemek için üçlü mırsralardan oluşan kıtalardaki etkileri derinlemesine incelemek ve Thomas'ın bu şiiriyle amaçladığı hedef kitlesine daha fazla ışık tutmak amacıyla hazırlanmıştır. Çalışma, Thomas'ın ölümü reddetmek için vurguladığı başarısızlıkların ve pişmanlıkların, insanları dünyada daha fazla kalmaya istekli olmaya motive etmekte yetersiz kaldığını ortaya koymaktadır.

1 Öğr. Gör., Kütahya Dumlupınar Üniversitesi, Lisansüstü Eğitim Enstitüsü, (Kütahya, Türkiye), mahmut.kayaalti@dpu.edu.tr ORCID ID: 0000-0002-6970-2313, [Araştırma makalesi, Makale kayıt tarihi: 21.07.2021-kabul tarihi: 20.08.2021; DOI: $10.29000 /$ rumelide.984784]

RumeliDE Dil ve Edebiyat Araştırmaları Dergisi Osmană̆a Mahallesi, Mürver Çiçeği Sokak, No:14/8 Kadıköy - ISTANBUL / TÜRKIYE 34714 e-posta: editor@rumelide.com tel: +90 $5057958124,+902167730616$
Address

RumeliDE Journal of Language and Literature Studies

Osmanağa Mahallesi, Mürver Çiçeği Sokak, No:14/8

Kadıköy - ISTANBUL / TURKEY 34714

e-mail: editor@rumelide.com

phone: +90 505 7958124, +90 2167730616 
Anahtar kelimeler: Dylan Thomas, ölüm, neo-romantik, kırkların şiiri, nazik

\section{Introduction}

Dylan Thomas's "Do Not Go Gentle Into That Good Night” has found itself in many studies in the literature. When these studies are examined, the explanations of what Thomas meant with his verses and the metaphors he used draw attention. Although the superficial meanings through the work's lines have been discovered, there are very few studies on these meanings' philosophy. For example, Thomas delivers with the lines - "wild men who caught and sang the sun in flight, and learn, too late, they grieved it on its way" (Thomas, 1952, l. 10-11) - that some people waste their time and regret it. For this reason, he argues, they should not accept death. However, further meanings covering the deep causes of rejecting death fall short to comprehend the poem better.

By holding the shortcomings mentioned above, this study evaluates "Do Not Go Gentle Into That Good Night" by Dylan Thomas more deeply by shedding light on his poetry style. Before interpreting the work, Thomas's character as a neo-romantic poet, and his point of view about death are briefly discussed.

\section{Dylan Thomas and Romantic poetry}

Unlike his contemporaries, Dylan Thomas, by standing away from modernism, formed his identity as a poet with the tenors of the romantic movement. Rather than focusing on individual personalities in society, he developed his poems within a spiritual framework (Ismael, 2019, p. 1). For Thomas's romanticism, Perkins asserts that "he had the mystical intuitions, emotional intensity, personal utterance, and natural imagery of a poet in the Romantic tradition" (1976, p. 171). From this aspect, he shares the typical characteristics of early Romantics in forming his poetry style. More openly, Thomas cherished human emotions instead of reason, and praised nature-belonged objects in transmitting his feelings through his lines. Besides, despite living in a politically turbulent period ${ }^{2}$, neither war nor the striking realities of modernisation are included in his poems. Instead, the innocence of childhood, human interaction with nature, and separation from the world, that is, death, are the main themes of Thomas's poems (Jain \& Singh, 2016, pp. 451-452). In Thomas's own words: "Poetry ... is the record of my individual struggle from darkness to some measure of light" (as cited in Castro Hidalgo, 1999, p. 145).

His attachment to the matter of death in his poems makes Thomas distinctive in the literary environment. He ignores death's harsh absoluteness by regarding it as a facet of the continuous course of life (Perkins, 1976, p. 178). To him, as soon as the embryo appears in the mother's womb, death is a present and potential threat to wipe it out. Regardless of the stage of the embryo's life, whether it is in childhood or old age, death is like an enemy waiting for him in ambush at any moment. Therefore, according to Thomas, every birth is actually a signal of death (Kumar \& Chhapra, 2019, p. 15). As long as there is birth/creation, death will also exist. Although the inevitability of death is a fact, Thomas takes an optimistic attitude towards it (Altındağ, 2019 , p. 16). He considers death as the soul's separation from its body that covers it like a cloth, and its liberation in another realm. Though the moment of death may seem like the end of the biological form, it is also the first moment of a new beginning. Hence, death is like moving from one room to another for Dylan Thomas (Sumathi \& Suresh, 2017, p. 49). Such a generalisation regarding death as a transition event between the realms is frequently encountered in Thomas death-based poems. In a sense, it might be said

Due to the World War II, Britain, at that time, experienced a number of issues at the state level, which affected the whole British community deeply.

Adres Address

RumeliDE Dil ve Edebiyat Araşttrmaları Dergisi $\quad$ RumeliDE Journal of Language and Literature Studies

Osmanağa Mahallesi, Mürver Çiçeği Sokak, No:14/8 $\quad$ Osmanağa Mahallesi, Mürver Çiçeği Sokak, No:14/8

Kadıköy - İSTANBUL / TÜRKIYE 34714 Kadıköy - ISTANBUL / TURKEY 34714

e-posta: editor@rumelide.com $\quad$ e-mail: editor@rumelide.com

tel: +90 505 7958124, +90 216773 o 616 phone: +90 505 7958124,+90 2167730616 
that death is not frightening for Thomas, but rather it is an occurrence that opens up different universes to him.

Thomas's perspective on death is, in fact, not much different from the early Romantics, who underlay the frame of the Neo-romantic movement Thomas pioneered. For example, like Thomas, William Blake speaks of death as changing places. It is not an end but a gate to a new beginning (as cited in Symons, 1907, p. 270). William Wordsworth's We Are Seven ${ }^{3}$ (1798), Percy Bysshe Shelley's Ode to West Wind ${ }^{4}(1819)$ and John Keats' Ode to a Nightingale 5 (1819) approach death in a promising manner, too. Thomas likely inherited the motifs of death in his poems from those early Romantic poets and was inspired by their mindset.

\section{What does “Do Not Go Gentle Into That Good Night" say?}

Even though Thomas originally wrote the poem in 1947, it was first published in a magazine - Botteghe Oscure - in 1951, then appeared in his Collected Poems in 1952. While it is just one of Thomas's many deathbased poems 6 , "Do Not Go Gentle Into That Good Night" is also known as the work that Thomas attributed to his moribund father, David John Thomas (Ellis, 2014, pp. 126-127; Janes, 2018, p. 175), who was diagnosed with throat cancer at that time (Ackerman, 1994, p. 132). The poem asserts that death is the fact that no living being can avoid. However, this does not mean that one should give up everything and surrender to death immediately; instead, people should struggle to win more time before dying. Throughout the poem, by referring to various groups of people, Thomas suggests a number of reasons for their struggle with death.

The poem is opened with a confusing statement that is also the title of the work - Do not go gentle into that good night (1. 1). It warns not to be enthusiastic in approaching that good night, that is death. Despite the non-gentle accepting of death, Thomas ornaments that night with an adjective - "... into that good night." Readers may wonder why death is identified with goodness if it is to be fought against. This usage, of course, does not indicate that Thomas deems death as a pleasant event; yet, as a reflection of his fierce feelings for death, he utilises the adjective to represent his ironic intelligence (Ma, 2020, p. 82). In the following lines of the tercet, "night" is compared to "light" to stress the requirement of living over death:

Old age should burn and rave at close of day;

Rage, rage against the dying of the light (ll. 2-3).

He insists people should stay in the light as much as possible, and not welcome death peacefully. On the other hand, for the gentleness of the action, Holbrook alleges a striking claim: "The word 'gentle' has beneath it a fierce hatred, a wish that the father should suffer more ..." (2014, p. 197). He means that Thomas begrudges his father a peaceful death, so he wishes his father would go to death, not in happiness but in pain. Since any other author has not voiced such an allegation, Holbrook's statement shows up as a doubtful argument. Many sources indicate that Thomas had a satisfying relationship with his father and a solid emotional bond (Janes, 2018, pp. 39-40; Goodby, 2013, p.51). In one of his letters, he mentions his father as: "I ... grew up to be a sweet baby, a precocious child, a rebellious boy, and a morbid youth. My father was a schoolmaster: a broader minded man I have never known" (Thomas, 1986, p. 43). So, it is evident that

(Wordsworth \& Coleridge, 2013, p. 46).

(Barcus, 1996, p. 387)

(Keats, 2001, p. 270)

Some of others are And Death Shall Have No Dominion (1933), After the Funeral (In Memory of Ann Jones) (1936), A Refusal to Mourn the Death, by Fire, of a Child in London (1945),

Adres Address

RumeliDE Dil ve Edebiyat Araştırmaları Dergisi Osmanağa Mahallesi, Mürver Çiçeği Sokak, No:14/8 Kadıköy - ÍSTANBUL / TÜRKIYE 34714 e-posta: editor@rumelide.com

RumeliDE Journal of Language and Literature Studies Osmanağa Mahallesi, Mürver Çiçeği Sokak, No:14/8

Kadıköy - ISTANBUL / TURKEY 34714 tel: +90 505 7958124, +90 2167730616

e-mail: editor@rumelide.com

phone: +90 $5057958124,+902167730616$ 
Thomas did not have a hostile sensation toward his father, and through his lines, wished him to stay longer in the world.

Though wise men at their end know dark is right,

Because their words had forked no lightning they

Do not go gentle into that good night (1l. 4-6).

The expression "... know dark is right" proves that the wise men are well aware of the ultimate destination that is nothing but death. However, they still have a responsibility before dying. According to Thomas, these people should not leave the world enthusiastically since they could not create their effect on the earth. "Lightning" in the line represents the illumination expected from wise men (Christie, 2014, p. 170). While there is still work to be accomplished, and the world needs to be changed and governed by the mind, Thomas emphasises that it is not right for these clever men to accept death immediately. Indeed, Thomas likely regards their effect as inefficient or ultimately futile. Either they have accomplished some of their duty, and the rest is awaiting, or they have not done anything remarkable. Whatever the situation is, they should not just wait for death.

Though the pointlessness of waiting for death is highlighted through the lines, Thomas appears to be filled with the desire for life. This passion actually constitutes the basis of social benefit rather than individual interest. A person, especially a wise person, who reads these lines might ask why one should have so much effort and wish to stay in the world, knowing that there is death at last. In this case, negligence may prevail in human nature, and disruption may occur in the course of developments that can potentially affect humanity. In other words, the fact that all sacrifices are incapable of hindering death may cause people not to care much about worldly affairs and indirectly the development of science. At this point, Thomas addresses people not to give up their pursuits and to continue their struggle until the moment of death. Only in this way can concrete steps be taken for humanity.

Wild men who caught and sang the sun in flight,

And learn, too late, they grieved it on its way,

Do not go gentle into that good night (11. 10-12).

A similar approach to the above can be observed in Thomas's call for "wild men." The people in this group, who are away from sorrow and burden, spend their lives in joy and pleasure (Christie, 2014, p. 171). When death finds them, they realise how unworthy they have spent their lives and regret, but this regret can no longer change anything. Therefore, even if one knows that death is a truth and it will come one day, one should not waste time in an unproductive way. Actually, this advice of Thomas is not for those who advocate the idea that people will die anyway, so let them enjoy their time; but for the ones who know that their days in the world are numbered and those who shape their lives with this consciousness.

As a result, "Do Not Go Gentle Into That Good Night" does not match the depiction of death in Thomas' other poems. The message that the poet wants to give to the readers is that although death is inevitable, people should not give up their struggle until the moment of death.

\section{Critique}

Primarily, it cannot be decided at first view whether "Do Not Go Gentle Into That Good Night" reflects Thomas's own thoughts on death, or whether it is a poem he wrote for a consolation to his ailing father.

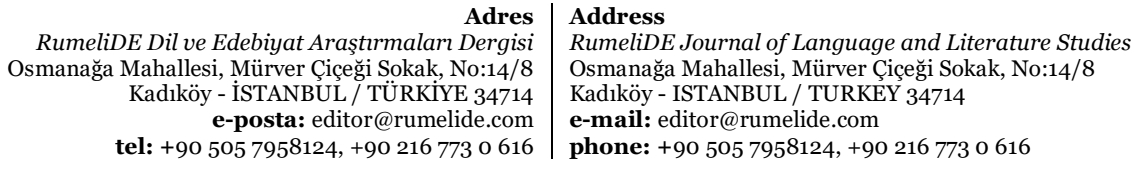


While many authors share a consensus on the poem's attribution to David Thomas, other authors still disagree. For instance, in the essay - "Dylan Thomas' Treatment of the Theme of Death in His Poetry" - it is stated that "as one cannot preach one's own father, the poem was never meant for Dylan's father" (Gill, 2017, p. 970). However, Thomas's direct addressing to his father via the last quatrain of the poem seems enough to refute Gill's statement: "And you, my father, there on the sad height" (Thomas, 1952, l. 16). Another point proving that the poem was written for his father is the year of publication. As stated above, there are approximately five years between the writing of the poem and its publication. It is not known whether or how much Thomas intervened in the poem during that five-year time. However, the poem's publication date coincides with the time of his father's death, which means that Thomas might have produced his poem as a kind of consolation for his father. In this case, it may not be a correct suggestion to mention that the poem contains Thomas's original thoughts on death.

Considering Thomas's other death-themed works, it can be seen that "Do Not Go Gentle Into That Good Night" has a different proposal than others and supports the opposite of the main idea in other poems. For instance, in "Death Shall Have No Dominion," he emphasises that death is not an end for the individual, and adds, for consolation, that the soul will be manifested in another universe after death (Mahmood, 2017, p. 211; Ackerman, 1994, p. 87; Stoddart, 2015, p. 136). In contrast, "Do Not Go Gentle Into That Good Night" shows death as a concept that stops the wheel of life and therefore, one must fight until the moment of death. Although "Do Not Go Gentle Into That Good Night" constantly emphasises the importance of fighting to the end, it does not provide the motivation to achieve this. In order not to be regretful of the ideals that people did not do or failed to achieve, this struggle is asked to maintain until the last breath; however, they fall short of giving the necessary enthusiasm to the reader to challenge death truly. How can one waiting for death in the bed be expected to resist? Considering that he published this poem at the age of 38 and is full of the joy of life, Dylan Thomas might be said to write it to make his ill father a little bit happy, rather than providing his reader with tangible reasons to oppose death. If he had experienced older ages and written this poem at that time, his thoughts then could have differed from the present one.

On the other hand, Thomas, who advocates not going to death willingly due to the alleged reasons he has presented, does not cover the situations that make death an acceptable phenomenon. If wise men had fulfilled their goals, wild men had not regretted but enjoyed their life, and his father had not been sick, would Thomas have accepted death gently? Regardless of person or lifestyle, the poem does not show the maturity to accept death. In this case, dying turns into an incident that puts an end to life and wipes off all people's ideals and hopes. According to Thomas, whatever people do, they will not be satisfied with what they have experienced throughout their lives; and they will always have an excuse not to be defeated by death. Although this one-sided approach of the poem has fairness in supplying courage to fight against dying, it also has an aspect that can lead people to pessimism and despair.

\section{Conclusion}

Dylan Thomas, one of the leading figures of the Neo-romantic movement in the 1940s, focused on emotion, nature and death in his poetic style. Given the approach in his poems dealing with death, it is observed that Thomas sees death not as an end but as the beginning of a new life. However, his well-known anti-death poem "Do Not Go Gentle Into That Good Night" approaches death as a life stopper, and nothing beyond it. Although the poem touches upon the importance and necessity of gaining more time from life, it does not explain comprehensively why and how this action will be performed. Personally, the poem stands out essentially as Thomas' resentment at the destructive effect of death. Thus, good or evil acts in the world, or

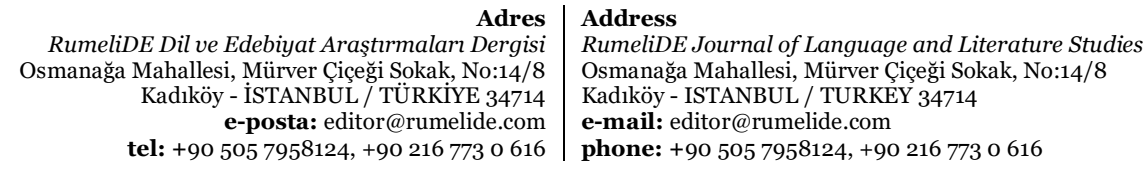


his father's illness - a crucial reason in the poem's production - are not the excuses Thomas actually made for more of survival. His central disturbance is that death is a destructive concept; everything ends with it.

\section{References}

Ackerman, J. (1994). A Dylan Thomas Companion. London: Palgrave Macmillan. https://doi.org/10.1007/978-1-349-13373-4

Altındağ, Z. (2019). Ecocentric Polyphony: The Subversion Of Dualistic Thinking In Dylan Thomas's Poetry (Thesis). Middle East Technical University. https://etd.lib.metu.edu.tr/upload/12622944/index.pdf

Barcus, J. E. (1996). Percy Bysshe Shelley: The Critical Heritage (1st ed.). UK: Routledge.

Castro Hidalgo, M. D. Á. (1999). Confronting opposites optimistically with Dylan Thomas. Revista de Filología y Lingüística de La Universidad de Costa Rica, 25(1), 143-150. https://doi.org/10.15517/rfl.v25i1.20522

Christie, W. (2014). Dylan Thomas: A Literary Life (Literary Lives) (1st ed.). London: Palgrave Macmillan.

Ellis, H. (2014). Dylan Thomas: A Centenary Celebration. Bloomsbury USA.

Gill, R. (2017). Dylan Thomas' Treatment of the Theme of Death in His Poetry. International Journal of English Language and Literature in Humanities, 5(9), 966-975. https://ijellh.com/OJS/index.php/OJS/article/view/2397/2318

Goodby, J. (2013). The Poetry of Dylan Thomas: Under the Spelling Wall. Liverpool: Liverpool University Press.

Holbrook, D. (2014). Dylan Thomas: The Code of Night. London: Bloomsbury Academic.

Ismael, N. A. (2013). Dylan Thomas:The Vision of Death as a Prologue to a New Life. The Journal of the College of Languages, 27, 1-13. https://jcolang.uobaghdad.edu.iq/index.php/JCL/article/view/277

Jain, U., \& Singh, R. (2016). The Use of Aesthetic Symbols and Imagery in the Poems of Dylan Thomas. International Journal of English Language, Literature in Humanities, 4(6), 450-457. https://ijellh.com/OJS/index.php/OJS/article/view/1479/1433

Janes, H. (2018). The Three Lives of Dylan Thomas (2nd ed.). Wales: Parthian Books.

Keats, J. (2001). Complete Poems and Selected Letters of John Keats (E. Hirsch, Ed.). New York: Modern Library.

Kumar, A., \& Chhapra, B. (2019). Treatment of Theme of Death in the Poems of Dylan Thomas. Journal of Emerging Technologies and Innovative Research, 6(2), 14-19. http://www.jetir.org/papers/JETIR1902B05.pdf

Ma, H. (2020). A Functional Stylistic Analysis of “Do not Go Gentle into That Good Night." Review of Educational Theory, 3(3), 79-83. https://doi.org/10.30564/ret.v3i3.1890

Mahmood, W. S. (2017). Thematic Analysis in Two Poems Written by Dylan Thomas. Arab Journal of Sciences \& Research Publishing, 3(1), 205-214. https://doi.org/10.26389/AJSRP.W130817

Perkins, D. (1976). A History of Modern Poetry: From the 1890s to the High Modernist Mode. Harvard: Belknap Harvard University.

Stoddart, S. (2015). Mediating the Dominion of Death in Prehistoric Malta. In C. Renfrew, M. Boyd, \& I. Morley (Eds.), Death Rituals, Social Order and the Archaeology of Immortality in the Ancient World: 'Death Shall Have No Dominion'(pp. 130-137). Cambridge: Cambridge University Press. doi:10.1017/CB09781316014509.009

Sumathi, N., \& Suresh, P. (2017). Life in Death a Critique of Dylan Thomas Select Poetry. International Journal of English Research, 3(4), 48-51.

http://www.englishjournals.com/archives/2017/vol3/issue4

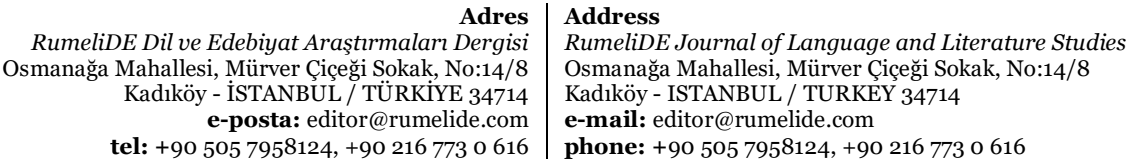


Symons, A. (1907). William Blake. New York, US: E. P. Dutton and Company.

Thomas, D. (1952). Collected Poems (1st ed.). J. M. London: Dent \& Sons LTD.

Thomas, D. (1986). The Collected Letters of Dylan Thomas (P. Ferris, Ed.; 1st ed.). Macmillan Publishers.

Wordsworth, W., \& Coleridge, S. T. (2013). Lyrical Ballads: 1798 and 1802 (Oxford World's Classics) (F. Stafford, Ed.; 1st ed.). Oxford: Oxford University Press.

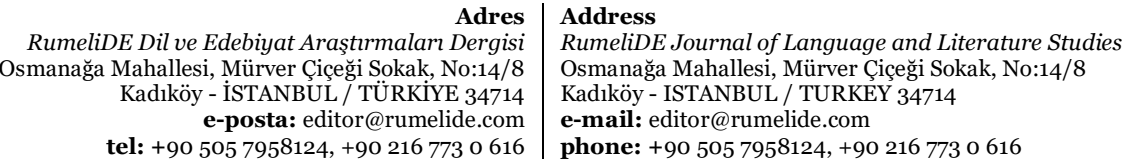

